Print ISSN: 2233-4165 / Online ISSN: 2233-5382 doi:http://dx.doi.org/10.13106/ijidb.2018.vol9.no3.57.

\title{
Strategy of Market Spread-Commercialization in EVs Industry : Visegrad and Nordic Countries* \\ $\mathrm{EVs}$ 산업의 시장파급과 상용화의 전략비교 : 비셰그라드 그룹과 북유럽 협의체와의 산업역량중심으로*
}

\author{
Dae-Sung $\operatorname{Seo}($ 서대성)**
}

Received: February 11, 2018. Revised: March 3, 2018. Accepted: March 15, 2018.

\section{Abstract}

Purpose - The purpose of this study is to classify that the quality factors for comparing the Visegrard Group with the Nordic Council have historical similarities against Germany and the Soviet Union. However, this is because in the integrated European market, the competitiveness possessed by the two groups of countries is invested in the priority order to grow.

Research design, data, and methodology - The study was conducted on the research design, and the reason for trying to compare the competence of the automobile industry in the assessment of industrial capability is that the Visegrard Group focuses on automotive production and the Nordic Association focuses on the commercialization of the automobile(market). In this study, searching and quantifying indirect evidence was made through standards are more complementary in Europe since each country acts like the role of the European automotive industry for example, which is different from the realistic evaluation criteria, are more important than those of the United States(first in the world) or Germany(first in Europe).

Results - The results of this study are as follows: In the global EV market U.S.(export: \$2.62 billion /share: $36.7 \%$ ), Germany(\$ 1.29 billion /18.1\%), France(\$390 million $/ 5.4 \%)$, United Kingdom(\$380 million /5.4\%), and South Korea(\$320 million/ 4.4\%). South Korea's share of the EV market is $4.4 \%$, while TSI reaches at +0.9 which measures the comparative advantage of a specific commodity in the world trade market. There is great potential for evaluated as products processing in export competition. But, commercialization, standardization, and overall market expansion did not have a positive impact on global satisfaction.

Conclusions - EVs put importance on various utilities. So this suggests that Korea's exports to the EU, including the Visegrard Group, should be more focused on marketability when illuminating with a sharing industrial system under the European Union. It is necessary to specialize in manufacturing and commercialization by country(region) to prepare sharing economy and blockchain in order to create a smart-sharing city linked on artificial intelligence, as the commercialization of electric vehicles, which will have a larger growth rate than that of manufacturing in the fourth revolutionary era.

Keywords: Manufacturing, Commercialization, EVs, Visegrad, Nordic, Smart City, Blockchain.

JEL Classifications: C12, M11, N94, R12, O32.

* This paper was revised one that presented at the conference of the Third European Union Trade and Industry Forum, Ministry of Trade, Industry and Energy, October 27, 2017.

** Professor, Dept. of Padeia, Sungkyul University, Korea. Tel: +82-392-0206, E-mail: dais3s@gmail.com
1. 서론

1.1. 연구목적

전기자동차산업은 4차 혁명산업에서 핵심적인 역할을 한다. 그 EVs(electric vehicles)의 보급에 따른 기존의 자동차 기업의 패러다임이 바뀌고, 4차 산업시장에서 상용화가 유럽 국가 간 의 협력으로 형성되고 있다. 유럽에서도 EVs는 보이지 않는 
특화된 관계를 형성하고 있으며, 비셰그라드 그룹을 북유럽협 의체와 비교한 요인은 독일과 소련에 대항한 역사적 유사성이 존재하기 한다. 그러나, 이는 통합유럽의 역내 시장에서는 두 그룹국가의 보유한 경쟁력을 우선순위로 투자하여 성장시키기 때문이다(Ambroziak, 2012). 산업역량 평가에서 자동차산업의 역량을 비교하려는 이유는 비셰그라드 그룹은 자동차 생산 부 문에, 북유럽 협의체는 자동차(시장)상용화 부문에 치중하고 있다. 전기자동차 산업 분야에서 세계 최고수준인 미국(세계 1 위) 또는 독일(유럽 1위)과 현실적인 평가 비교하는 기준 보다 는 다르게, 통합유럽 역내에서 상호보완적 역할과 특화로써 그 기준이 더 중요한 작용하고 있기에 이를 방증하고자 한다. 현 재 세계 전기자동차 시장은 미국(수출금액 26.2억 달러/ 점유 율 $36.7 \%)$, 독일(12.9억 달러/18.1\%), 프랑스(3.9억 달러/5.4\%), 영국(3.8억 달러/5.4\%), 한국(3.2억 달러/4.4\%)이다(UN, 2017). 한국의 전기자동차 수출시장 점유율은 $4.4 \%$ 이나, 특정상품의 세계 무역시장에서의 비교우위를 측정하는 무역특화지수 (Trade Specification Index: TSI, 최저-1. 최고+1) TSI는 +0.9 수준에 해당하며(KITA, 2017) 매우 높은 수출경쟁 잠재력을 보유한 것으로 평가된다. 반년에 노르웨이는 2016년 국내시장 점유율이 $28.76 \%$ 로 세계 최고이다(OECD, 2016). 이에 따라 서, 전기자동차 관련 산업부문을 총체적으로 볼 때는 상용화, 표준화 및 전반적인 시장 확대가 글로벌 만족에 긍정적인 영 향을 미치지는 않고 있기에 이를 확인하고자 한다.

따라서 본 연구의 본질은 실제 융합에서 검토해 볼 때, 비 셰그라드 그룹을 포함한 우리나라의 대 EU 수출에 미치는 시 사점은 4차 혁명시대에는 전기자동차의 상업화가 제조보다 성 장규모가 크게 나타나기에 블록체인기술과 결합한 표준화 시 장성에 더 치중해야 하는 이유를 검토한다.

\section{2. 이론적 배경}

\subsection{1. 그룹의 유사성}

동맹(alliance)은 시너지 효과를 활용하기 위한 제휴를 맺는 기업 간의 전략적 상호 작용을 고려하듯(Panico, 2017), 국가 의 동맹 시너지도 경제적 실리를 바탕으로 형성되었다. 과거 비셰그라드 동맹과 노르딕(칼마르) 동맹이 동일한 14세기에 형 성되었다. 그 협력은 중부유럽의 경우, 중동부 유럽 내에서 정 경유착이 되어온 합스부르크가와 한자동맹으로 부터 경제통로 를 열어 경제를 재건하고자 하였다. 유사하게도 북유럽의 경 우, 노르딕 협의회(N5)의 근원도 9-10세기에 걸쳐서 노르만인 에 의해 14세기 북유럽 3국(덴마크·스웨덴·노르웨이)은 독일 기사단이나 무역독점화로 이룬 한자 동맹의 진출과 대항하면 서 발전했으나, 이후 덴마크를 중심으로 한 북유럽 3국의 종 속관계의 연합 왕국이 형성되었다. 이 연합 왕국은 1523년 스 웨덴이 분리 독립할 때까지 계속되었다. 이는 북유럽의 노르딕 그룹으로 결성된 것과 유사하다. 과거, 1335년 동유럽 비셰그 라드 동맹이 결성되고 62년 이후, 1397년 북유럽 칼마르 연합 으로 이어진 것과 일치한다. 결국은 발트해 한자동맹의 무역 로를 동부 유럽으로 연결한 계기가 되었고, 북부 유럽 역내에 서도 확장해 나갔다. 1397년 칼마르 연합은 스웨덴-노르웨이덴마크의 연합 왕으로 즉위할 때 핀란드도 이에 편입되었다. 결과적으로 1521 년 칼마르 연합은 붕괴되었으나 스웨덴 구스 타브 1 세 바사는 핀란드를 편입시키면서 안정된 국가를 형성 하였다. 1550년에는 헬싱키가 건설되었지만 헬싱키는 처음 2
백년간은 어촌 도시에 지나지 않았다. 이 무렵 16세기 비셰그 라드 동맹을 통해 동유럽의 헝가리 부다페스트는 비엔나에서 벗어나서 독자적인 동서무역의 허브로 성장과 오스만투르크의 침략의 대응 등 이후 중부유럽개발의 소생을 위한 중요한 토 대가 되었다.

Newby(2009)는 북유럽 협의회 자체가 편향 후 영국이 거의 균등한 이익의 파트너십을 반영하기 위해 고립 관계를 재협상 하는 방법의 일례로 보고 있다. 그러나 제2차 세계대전 이후 북유럽은 국가 간에서는 협력연대의 필요성이 다시 강조되었 다. 그 이유는 전쟁 중, 스웨덴은 중립을 표방해 전쟁을 면했 지만 덴마크, 노르웨이는 독일의 침공을 받았고, 핀란드는 소 련의 침공을 받았기 때문이다. 이 국가들은 북유럽 중립동맹을 구상했으나 덴마크와 노르웨이, 아이슬란드가 북대서양조약기 구NATO에 가입하면서 북유럽 중립동맹은 추진되지 못했다. 그이후 경제적 관세동맹을 추진했으나 좌절되었다. 북유럽 국 가들은 군사와 정치를 제외한 경제·사회·문화면에서 연대를 강화하는 목적으로 전환하였고, 이러한 토대로 1952년 에 북 유럽이사회가 결성으로 이어졌다. 이는 1952년 2월에 노르딕 협의회(Nordic Council)는 북유럽 각국들의 공통관심사와 상호 협력과 유대를 1995년 유럽연합에 가입이후에도 계속 유지 해 오고 있다. N5는 발트 3국과 북유럽 이사회 간의 공식적인 협 력 관계가 수립되어 1992년 북유럽 이사회와 발트 의회 간의 협력 협정으로 NB8을 구축하였다.

동유럽의 비셰그라드 동맹도, 1989년 구소련이 붕괴이후, 다시 비셰그라드 그룹으로 재결성한다. 이는 노르딕 협의체인 재결성과 그 역사적 시기는 다르지만, 유사한 경제사적 흐름을 같이 한다. 과거 $14 \mathrm{C}$ 비셰그라드 동맹이 북부의 폴란드에서 발칸남부 크로아티아까지 연결되는 무역로를 개방하기 위해서 였듯이, $20 \mathrm{C}$ 비셰그라드 그룹으로 공산주의 독재의 잔재를 제 거와 구 소비에트 블록으로부터 에너지 및 경제적인 자립을 위한 협의체로 다시 시작하여 경제적 협력을 도모하였다. 2004년 EU 가입 이후에도 비셰그라드를 통해서 동유럽의 발 언권을 가지려 한다.

\subsection{2. 두 그룹의 역할론}

국제 관계에서 역할 이론은 Harnisch et al.(2011)의 언급처 럼, 정책 역할의 행태에 대한 광범위한 경험적 분석에서 나온 다. V4(비셰그라드 4개국)는 자본주의 안에서 사회민주주의를 실현한 북유럽국가와는 달리, 사회주의와 자본주의를 모두 경 험한 국가들로써, 단기간에 경제적 성장을 보이고 있는 국가들 이다, 지리적인 위치와 상관없이, 제 3 국과도 공동으로 협업한 다. 유럽연합과 나토의 회원국이면서, 비세그라드 4국을 하나 의 국가로 가정할 경우 비세그라드 그룹은 유럽에서는 5 번째 이고 세계에서는 12 번째 경제 강국이 되기 때문이다. 그만큼 현재에도 비세그라드 그룹의 협력을 요구한다.

반면 현재 비셰그라드 그룹은 각국마다 GDP의 $20 \%$ 이상 차지하는 자동차산업에 중점을 두고 있다. 이는 유럽의 자동차 제조기지와 산업개발로 인한 전기 에너지원의 안정적인 확보 와 기술도입, 상용화라는 측면에서도 강조되고 있다. 유럽연합 내의 수출 통로를 이용하여 경제적인 자립을 위해 비세그라드 국가들 간의 유사한 산업구조로 인해 비셰그라드 국가들 간의 경쟁을 해 왔다.

반면에 북유럽은 급속도로 전기자동차 실용화와 더불어 이 에 걸맞은 새로운 스마트시티의 구축망을 설계하고 있다. 북유 
럽협의체 간의 전기자동차 제조 및 $\mathrm{R} \& \mathrm{D}$ 는 스웨덴이 주축을 이루고, 자동차 ICT, 소프트웨어 기술은 핀란드가 담당하며, 전기차의 시스템구축과 에너지원은 노르웨이가, e-교통안전과 전기차 환경은 덴마크가 일조 하고 있다. 이처럼 경쟁성장보다 는 협업체로써, 시장을 세분화하며, 앞으로 전기차의 시장 상 용화로 인해 스마트시티에 요구되는 세계시장의 표준화를 구 현하고자 한다. 따라서 본 연구는 각각 역할에 따른 시장 확대 와 긍정적인 역할관계가 있음을 각각 분석하였다.

비셰그라드 4그룹의 발전 방향은 노르딕 협의회처럼, V4는 실제 유럽통합 노력의 대안으로 생성된 것이 아니며 기존 기 능의 $\mathrm{EU}$ 구조와 경쟁하는 것도 아니다. 비셰그라드 그룹의 활 동은 유럽연합을 포함한 주변 국가들과의 국제 관계의 질서를 벗어나거나 이웃하는 국가를 소외시키기 위한 것도 아니다. 그 룹의 협의체의 시초는 모든 국가들과의 협력을 위해서 목표로 하고 있다. 상대적인 목표는 유럽의 민주주의 발전을 다방면에 서 발전시켜 선도하려는 것에 있기 때문이다.

글로벌 금융위기 이후 V4(비셰그라드 4개국) 중 가장 크게 성장하고 있는 나라는 폴란드, 슬로바키아이다. 폴란드는 소비 경제도 지속적으로 GDP대비 $60 \%$ 이상을 유지해 왔으며, 이 는 경제성장에 안정화를 가져오고 선순환의 역할을 하고 있다. 미국의 금융위기, 2008년 이후부터는 GDP의 규모가 $24 \%$ 이 상 성장했다. 유럽에서 가장 빠르게 성장하는 국가이다. 반면 에 폴란드와는 달리, 헝가리는 소비경제가 위축되면서 낮은 회
복세를 가져왔다. 사실상, 헝가리, 폴란드, 체코, 슬로바키아는 항상 단일 시민의 일부로 지내 왔다. 예를 들어, 문화나 지적 가치, 다양한 종교적인 전통의 뿌리 등을 공유하였다. 이는 그 들이 비셰그라드 그룹을 통해서 더 보존하고 강화되길 바라기 때문이다.

\section{3. 연구모델}

\section{1. 비셰그라드 4그룹과 노르딕 협의회의 산업구조 비교}

유럽에서 디젤차량의 판매가 상대적으로 높아, 향후 디젤 VS 가솔린 VS 친환경차의 구도를 면밀히 관찰해야 할 필요가 있다. 여기에는 다국적 기업들의 생존전략과도 같이한다. 전기 차나 자율주행 기술과 같은 미래보다는 이머징 마켓의 성장과 내연기관의 최적화, 플랫폼 사용 확대, 생산기지 조정 등, 보 다 현실적인 문제에 집중되어 있다. 이러한 관점에서 살펴 볼 때 중소기업들은 더욱 현실적 문제에 집중하기 때문이며(Coo, 2017), 현재 자동차 산업에서 기업들의 생존이 전제되어야 전 기자동차의 미래가 있음을 역설하는 이유이다.

$<$ Table 1> Generosity Analysis of V4(Visegrad) Competition Area and N5(Nordic) Cooperation Area

\begin{tabular}{|c|c|c|}
\hline & V4 : Competition area among countries & N5 : Priority areas of Nordic cooperation \\
\hline \multirow{4}{*}{$\begin{array}{l}\text { Heterogeneous } \\
\text {-factors }\end{array}$} & $\begin{array}{l}\text { Competition } \\
\text { - Strengths: New Automation Factory(world class player). } \\
\text { Improvement in quality efficiency more than } 300 \\
\text { sub-companies, productivity upward market. } \\
\text { - Weaknesses: Mostly FDI, foreign ownership base, } \\
\text { preferential government support only for major inventors. }\end{array}$ & $\begin{array}{l}\text { - Strengths: Nordic green power system with high } \\
\text { efficiency security(System development }+ \text { cooperation } \\
+ \text { new technology general tools }+ \text { electromagnet } \\
\text { facility) } \\
\text { - Weaknesses: Difficulty building a wide range of } \\
\text { systems. }\end{array}$ \\
\hline & $\begin{array}{l}\text { Demand } \\
\text { - Advantages: Access to EU market, Slovakia can not } \\
\text { play a major role to meet local needs. } \\
\text { - Disadvantage: High export dependence for production } \\
\text { cycle business. }\end{array}$ & $\begin{array}{l}\text { - Advantages: Consumer Authorization for Marketability } \\
\text { in Nordic. } \\
\text { - Disadvantage: High labor cost }\end{array}$ \\
\hline & $\begin{array}{l}\text { Relationship } \\
\text { - Favorable: Traditional strong machine industry, more } \\
\text { than } 40 \% \text { of local purchases, trying to establish IFC. } \\
\text { - Non-favorable: Cluster cohesion is insufficient(a few } \\
\text { inventor's patent led) }\end{array}$ & $\begin{array}{l}\text { - Favorable: Strengthening Nordic's robust power } \\
\text { system, currently, maintain high level of security } \\
\text { provided. } \\
\text { - Non-favorable: Government business welfare bias }\end{array}$ \\
\hline & $\begin{array}{l}\text { Factor } \\
\text { - Good: skilled/unskilled production workers, constant } \\
\text { infrastructure improvements, geographical proximity to } \\
\text { Austria and South Germany. } \\
\text { - Bad: Lack of management and engineering talent in } \\
\text { cluster growth, mobility of low wage labor. }\end{array}$ & $\begin{array}{l}\text { - Good: Market to better support marketing } \\
\text { appropriateness, blockchain. } \\
\text { - Bad: Movement of tax evasion, }\end{array}$ \\
\hline $\begin{array}{l}\text { Homogeneous } \\
\text {-personality }\end{array}$ & $\begin{array}{l}\text { Strengthen Visegrard 4's voice \& cooperation within the } \\
\text { EU. }\end{array}$ & $\begin{array}{l}\text { Strengthening the Nordic 5's voice \& sharing within the } \\
\text { EU. }\end{array}$ \\
\hline
\end{tabular}

Source: Author's own edited. 
여기서 전기자동차 상용화에 따른 에너지와 제조 산업의 인 센티브, 인프라 정책도 중요하다. 비셰그라드 국가 간의 경쟁 에 따른 소모와 손실 등이 앞으로의 발전에 저해되기 때문이 다. 이를 노르딕 국가들은 협력의 영역으로 제시하면서, 그 경 쟁영역을 구분하고 있기 때문이다.

비셰그라드 그룹의 경우, 농업용 바이오 가스 플랜트에 의 한 에너지 생산은 최근 Visegrad 국가에서 상당한 성장을 기 록하고 있다(Chodkowska-Miszczuk and Kulla and Novotny, 2017). 이 개발은 신재생 에너지원에서 생산되는 에너지의 비 율을 증가시키려는 유럽연합(EU)의 노력에 의해 강화되었다. 이 글은 Visegrad 지역의 전기자동차 관련 산업의 생산 개발과 에너지 정책의 역할을 평가하는 것을 목표로 하고 있다. 이를 살펴보면, 재생 가능 에너지원에서 에너지 생산을 위한 다양한 형태의 지원처럼, 전기자동차의 가격 체계 및 보조금에 따른 지 원을 포함한 가격 체계가 지배적인 영향을 미치고 있다.

\section{2. 연구모형(기술 지배력과 시장 지배력)}

\subsection{1. 비셰그라드 그룹에서 북유럽 협의체와 EU까지}

본 연구는 $\mathrm{EVs}$ 시장과 연계해서 상용화된 국제표준특허는 '기술 지배력'과 '시장 지배력' 모두를 갖게 된다. 이처럼 북유 럽에서 환경적인 요인을 배제해도 전기자동차 상용화를 선도 해 가는 이유는 기술 상용화로 인해 시장 표준화를 형성하여 기술력은 없지만 글로벌 시장 지배력을 형성하려는 목적도 내 포하고 있다. 더 나아가 전기자동차 파트너 다국적 기업과의 협 력으로 스마트시티를 건설로 새로이 발견되는 상용화 기술도 창출하여 세계시장을 선도하여 한다. 이점에서 비세그라드 국가 의 역할과 북유럽 국가의 역할이 분명하게 구분되어 보인다. 그 러나 V4의 규모와 성장성을 무시할 수 없는 실정이다. 북유럽 에서 유일하게 스웨덴의 높은 성장세는 전기자동차 산업에서 지속되기에 이에 따른 연구 모델을 다음과 같이 제시한다.

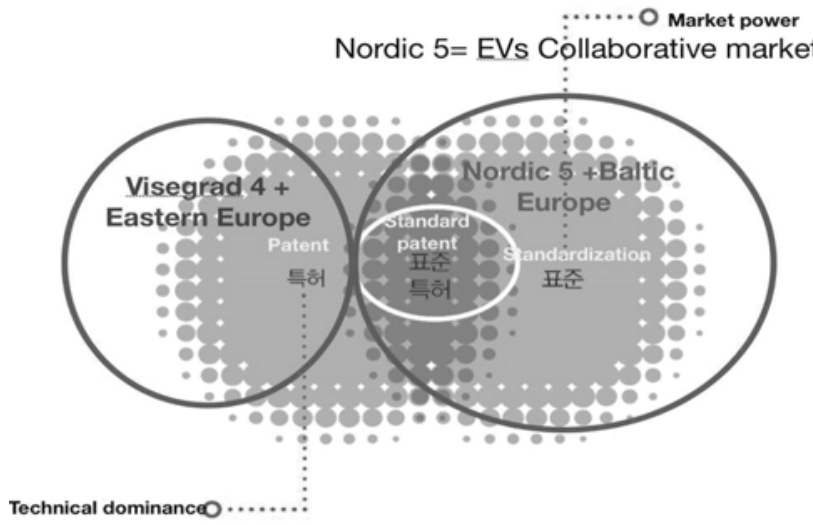

EVs export market $=$ Visegrad 4

Source: Author's own edited.

<Figure 1> Research model: Commercialization of Northern European EVs and manufactural export of V4

현재 스웨덴에서 전기를 공급해주는 고속도로인 e하이웨이 (e-Highway)가 개통했으며, $2 \mathrm{~km}$ 구간의 팬터그래프를 갖춘 하 이브리드 트럭에 보선을 이용해 전력을 공급해주는 형태를 취하 고 있다. 이는 스마트시티를 연결하는 e-고속도로의 일환이다.

반면에 과거 비셰그라드 국가가 기술 개발의 능력은 탁월했
다. 이는 단지 기술 지배력만 있을 뿐, 세계시장을 선도해 가 지는 못해 왔다. 또한 경제성장에 직면하고 있는 가장 큰 과제 중 하나는 전기차의 수요예측과 전력 증가의 관점에 있다. 이 는 오래된 전기 및 가스 인프라와 제한된 생산 및 전송용량에 문제가 되고 있다(Coo \& Seo, 2016).

$\mathrm{EU}$ 주요국의 전기차 보급이 가속화하고 있다. 각 국가들은 전기차 보급목표를 수립하고 적극적으로 전기차 보급을 위해 서, 보조금 정책과 충전인프라 구축 등으로 전략적인 정책을 전개하고 있다. $\mathrm{EU}$ 는 네덜란드(30개 충전소)-덴마크(23개)스웨덴(35개)—독일(65개)을 잇는 주요 고속도로 상에 공공 전 기차 충전시설 155 개를 구축하고 있다. 이를 위해 유럽 교통 지원프로그램인 범 유럽 네트워크(Ten-T)로 전기차 충전시설 확충에 지원되며, 총 예산 중 400 만 유로를 지원하고 있다. 이 러한 프로젝트는 북유럽 내에 전기차 사용자를 확대를 가속화 하려는 것이다. 또한 $\mathrm{EU}$ 는 전기차 충전 플러그를 단일화하여 통합 규격으로 채택하여 유럽의회 집행위 회원국 내에서 전기 차 충전 플러그 단일화하였다. 이는 전체 유럽뿐만 아니라 전 세계 전기차 시장에 큰 파급으로 작용하고 있다.

전기자동차의 관련 개발에 관해서 보면, 기존에 한국의 ICT 기술 와이브로가 유럽의 LTE 기술 표준화로 배제된 것처럼, 전기차 개발로 생산에서 수익의 확대보다는 전기차의 도시와 연계된 융합 기술 표준화로 시장 지배력을 강화하려는 것이 유럽 연합의 전략이기도 하다. 그 이전사례로, 유럽 시장에서 는 핀란드, 독일, 노르웨이, 스페인, 스웨덴, 영국 등지에서 LTE 시범서비스를 하였으며, 2010년 상반기에는 스웨덴과 노 르웨이에서 상용화가 되었다. 현재 전 세계 17 억 인구가 통신 가입하여 사용한다.

제조는 V4에서 융합시장 상용화는 노르딕에서 형성되고 있 는 실정이다. 전기차의 친환경으로 명명하기에는 부족한 전기차 의 배터리 생산/폐기까지 발생할 중금속으로 인한 오염, 처리비 용에 대해서는 유럽연합의 정책 관점과는 상반되기 때문이다.

$<$ Table 2> Automobile market share in emerging markets

\begin{tabular}{|c|c|c|c|c|c|c|c|c|c|}
\hline $\begin{array}{c}\text { Emerging } \\
\text { markets }\end{array}$ & U.S. & Europe & China & Japan & India & Brazil & Russia & Asean & others \\
\hline$\%$ & 20.1 & 18.4 & 23.3 & 6.1 & 3.2 & 2.9 & 1.9 & 3.3 & 20.8 \\
\hline
\end{tabular}

Source: KARI(2016).

\section{3. 연구방법}

\subsubsection{V4와 N5의 협업구축과의 관계분석}

두 그룹의 연구방법은 EVs를 통해서 스마트 모빌리티를 구 현하는 과정에서 혁신센터와 상용화율을 구분하여 분석하고자 한다. 현재 스마트도시와 연계한 북유럽화된 전기차 시스템의 장점은 <Table 3>로 비교하면 다음과 같다. 첫째, 배출 가스가 없고(Zero Emission Vehicles), 자동차 사고로 인한 사상자가 없는(Zero Fatalities On the Road) 사회를 구축할 수 있다. 둘 째, 인공지능 탑재로 인해 도시를 스마트한 교통과 안전을 이 끌 수 있다. 셋째, 3D 프린팅과 배터리, 차량내 엔터테인먼트 등 제조업 혁신기술의 적용으로 다양한 도시문화와 연계가 가 능하다. 유럽의 스마트시티는 '스마트 환경' 및 '스마트 이동' 관련 진행 사업과 전략이 $33 \%$ 와 $21 \%$ 이며, 다른 4 가지(스마트 거버넌스, 스마트 경제, 스마트 인간, 스마트 생활) 특성 관련 각각 약 $10 \%$ 정도이다(Kiat, 2016). 
$<$ Table $3>$ Current status of European cities by the type of smart city

\begin{tabular}{|c|c|c|c|c|c|c|}
\hline characteristic & $\begin{array}{c}\text { Smart } \\
\text { Governance }\end{array}$ & $\begin{array}{c}\text { Smart } \\
\text { economy }\end{array}$ & $\begin{array}{c}\text { Smart } \\
\text { Mobility }\end{array}$ & $\begin{array}{c}\text { Smart } \\
\text { Environment }\end{array}$ & $\begin{array}{c}\text { Smart } \\
\text { humanity }\end{array}$ & $\begin{array}{l}\text { Smart } \\
\text { life }\end{array}$ \\
\hline City number & $\begin{array}{c}85 \\
(14 \%)\end{array}$ & $\begin{array}{c}67 \\
(11 \%)\end{array}$ & $\begin{array}{c}125 \\
(21 \%)\end{array}$ & $\begin{array}{c}199 \\
(33 \%)\end{array}$ & $\begin{array}{c}52 \\
(9 \%)\end{array}$ & $\begin{array}{c}71 \\
(12 \%)\end{array}$ \\
\hline National city & $\begin{array}{c}\text { 1st group: } \\
\text { France, Spain, } \\
\text { Germany, Sweden, } \\
\text { UK, Italy/ } \\
\text { 2nd group: } \\
\text { Greece, Romania, } \\
\text { Hungary, Poland, } \\
\text { Estonia, Denmark }\end{array}$ & $\begin{array}{l}\text { 1st group: } \\
\text { Germany, Spain, } \\
\text { Italy, UKJ } \\
\text { 2nd group: } \\
\text { Sweden, } \\
\text { Netherlands, } \\
\text { Belgium, France }\end{array}$ & $\begin{array}{l}\text { 1st group: } \\
\text { UK, Germany, } \\
\text { Netherlands, } \\
\text { Spain, Austria, } \\
\text { Hungary, } \\
\text { Romania, Italy/ } \\
\text { 2nd group: } \\
\text { Northern } \\
\text { European cities }\end{array}$ & $\begin{array}{l}\text { 1st group: } \\
\text { Spain, UK, Italy, } \\
\text { Netherlands, } \\
\text { Belgium, Nordic } \\
\text { countries/ } \\
\text { 2nd group: } \\
\text { Other countries }\end{array}$ & $\begin{array}{c}\text { 1st group: } \\
\text { Germany,UK, } \\
\text { northern Spain, } \\
\text { northern Italy/ } \\
\text { 2nd group: } \\
\text { France, Sweden, } \\
\text { Benelux } \\
\text { countries }\end{array}$ & $\begin{array}{c}\text { 1st group: } \\
\text { Spain, Italy, UKJ } \\
\\
\text { 2nd group: } \\
\text { Northern } \\
\text { Europe, Austria, } \\
\text { Romania, } \\
\text { Germany, } \\
\text { Benelux } \\
\text { countries }\end{array}$ \\
\hline
\end{tabular}

Source: Author's own edited.

\subsubsection{V4의 부품소재 제조와의 관계}

\section{<리서치: R1> 슬로바키아}

현대기아자동차가 집중 투자한 슬로바키아의 경우, 2015년 에는 $11.5 \%$ 로 여전히 위기 전 수준에 도달하고 주변국 V4 경 제보다 훨씬 높았다. 잠재적인 성장은 장기 실업의 현상에 의 해 국민은 불안정해지고 특히 동부와 남부의 가난한 지역에 집중되었다. 청년 실업은 $\mathrm{EU}$ 에서 가장 높은 $30 \%$ 에 달했다. 슬로바키아의 급속한 경제 수렴에도 불구하고 지역 격차는 EU에서 가장 큰 편이다. 이는 일자리는 대부분 부유한 지역에 서, 특히 서부 지역과 브라티슬라바 근처에서 창출되기 때문이 다. 외진 지역의 빈약한 기반 시설은 덜 역동적인 지역에서 투 자와 고용 창출을 저해하고 낮은 노동 이동성, 학교에서 직장 으로의 전환 또는 실업에서 고용으로의 복귀라는 메커니즘이 악화되어 지역 불균형이 심화되기도 한다.

슬로바키아 자동차 산업의 초기 시대는 1991년 독일 자동 차 기업인 Volkswagens가 슬로바키아에 출시한 이후부터 시 작되었다. 중부 유럽의 폭스바겐 확장은 체코의 Skoda에서 시 작되었지만 같은 해에 슬로바키아 공화국의 BAZ 지분 $80 \%$ 를 계속 구매했다. 지역 내 생산 시설의 구식으로 인해 건물은 유 지되지만 새로운 장비와 기술에 투자했다. 슬로바키아 정부도 직원들이 주택을 쉽게 빌릴 수 있도록 계획을 제안하고 있으 나 성공할 경우, 일자리가 더 서북부 유럽으로 갈 수 있는 인 력들이 발생한다. 결과적으로 몇몇 산업계들은 세르비아 및 헝 가리와 같은 인접국으로부터 인력을 더 고용하고 있다는 실정 이다. 슬로바키아 인력수급에 대한 경향은 자동차업계가 급속 한 성장기를 누리고 있기 때문에 나타난다. 그러나 그 확장은 확대된 공장에서 일할 인력을 찾는 것과 동일한 자체 문제를 야기하였다. VW와 푸조 시트로엥은 모두 규모가 증가하고 Jaguar Land Rover는 슬로바키아의 기지를 주변 폴란드와 경 쟁지로 선택한 후 1년에 30 만 대를 생산할 수 있는 부지를 설 립하였다. VW는 추가로 1,500 명의 근로자가 필요했고, PSA는 또 다른 1,200 명을 고용해야 했다. 이렇게 증가하는 수요를 맞 추기 위해, 이 지역에 위치한 공급 업체는 수천 명의 고용 인 력을 찾아야 하기 때문이다.
현재 자동차 수요와 공급이 세계화되면서 지역 수요 조건은 플랜트 위치를 선택할 때 중요한 역할을 하지 못한다. 비세그 라드 국가는 유럽연합(EU)의 일원이 되었고, 유럽 시장에 5 억 인구의 관세가 적용되지 않음으로써, 분명히 이익이 되기 때문 이다. 그런 의미에서(더 비싼 차량 유형의 큰 고객 점유율로 인해), 특히 신규 역할 플레이어의 경우, $\mathrm{EU}$ 외부에 위치한다. 따라서 비세그라드 그룹의 자동차 수요는 수출에 의존적이며 제품 순환주기가 길어 영향력이 약하다. 경쟁 클러스터로 보 면, 유럽연합(EU)은 세계 최초의 자동차 제조업체였지만 최근 전기자동차의 도약 동안 중국에 의해 초과되었다. 앞으로 전기 자동차 산업은 유럽과 $\mathrm{V} 4$ 의 번영을 위해 매우 중요한 시기이 다. 슬로바키아의 경우, 이 분야는 1,200 만 명의 사람들에게 일자리를 제공하며 EU GDP의 $4 \%$ 를 차지하기 때문이다. 자동 차 제조 분야에는 $\mathrm{EU}$ 의 제조 고용의 $7.6 \%$ 를 차지하는 고도로 숙련된 2,300만 명의 일자리가 있다. 유럽 자동차 제조업체의 $60 \%$ 는 일반적으로 허용되는 수익성 수준인 $75 \%$ 미만의 용량 을 운영되고 있다. EU의 총 자동차 생산 능력은 연간 2,000 만 대이지만, 2013년 수요는 1,400만 대에 불과하다. 그러나 슬로 바키아는 느린 자동차산업의 출발 이후부터 전체 산업이 발전 하기 시작한 것이고 외국 기업의 출시로 인해 지역의 하청 공 급 업체와 네트워크를 육성하게 되었다.

대내외 관점에서 볼 때 슬로바키아는 자동차 클러스터에서 상당한 성장을 이루었다. 지난 15년 동안 세계 수출에서 차지 하는 비중은 4 배로 증가했으며 수출은 $2 / 3$ 로 증가했다. 슬로바 키아의 세계 수출 비중 $(0.11 \%)$ 과 비교할 때, 자동차 산업은(세 계 시장 점유율의 $1.6 \%) 14$ 배가 넘는 놀라운 수치이다. 또한, 자동차 그룹은 슬로바키아의 총 수출량이 $25 \%$ 이상으로 2000 년의 $1 / 3$ 이상을 차지하고 있다.

\section{<리서치: R2> 헝가리}

실제로 $\mathrm{V} 4$ 는 과거부터 전기차의 기술 지배력은 갖고 있었 다. 1828년에 헝가리(Hungary)에서 Anyos Jedlik에 의해 만들 어진 전기자동차의 전기모터가 시초였다. 전기차는 1839년 스 코트랜드의 로버트 앤더슨이 처음 개발한 시속 $36 \mathrm{~km}$ 이후 비 로써, 1899 년에 처음으로 $100 \mathrm{~km} / \mathrm{h}$ 의 속도가 가능해진 전기자 
동차인 벨기에의 "La Jamais Contente"가 생산되었다. 또한 가솔린 엔진도 헝가리 Janos Csonka와 Donat Banki는 1893 년 2월에 특허를 획득한 최초의 가솔린 기화기(내연기관 -carburettor)를 제작했다. Janos Csonka는 엔진 제조에 알루 미늄을 사용하기 시작한 첫 번째 제품이었으며 가솔린 엔진 용 제어 밸브와 고압 마그네토 점화 장치를 개발했다. 그러나 현재, 헝가리의 자동차 산업을 지배하는 기업은 스즈끼, 오펠 (제너럴 모터스), Skoda(폭스바겐 그룹) 및 포드 등 모두 외국 소유의 국내 제조업체이다. 2006년부터 5년 연속 축소되었던 자동차 생산은 2011-2012년에 다시 성장했고, 그 이후 건실하 게 확장되어 산업 생산량의 증가와 수출을 주도했다.

현재 자동차 산업은 헝가리 GDP 성장에 중요한 역할을 담 당하고 경제에 실질적인 도움을 주고 있다. 헝가리 신차 판매 량은 2015년 $14.1 \%$ 증가했다. 헝가리 도로 300 만 대의 평균 연령은 13 년에 가깝다. 헝가리 정부는 자동차 산업, 특히 1 차 및 2차 공급 업체를 새로운 투자를 유도하고 그 과정에서 새 로운 일자리를 창출하는 촉매제로 역할을 한다. 2015년에 헝 가리는 2009년에 48,000 대에 70,081 대의 새로운 승용차를 구 매하였다. 중형차는 다재다능한 기능과 저렴한 가격 때문에 가 장 대중화되고 있는 실정이다.

전기자동차와 하이브리드 전기자동차는 헝가리에서도 선호 도뿐만 아니라 필수품이 되고 있다. 그러나 헝가리는 여전히 전기 또는 하이브리드 자동차의 높은 소매가격을 보상하기 위 한 적절한 인센티브 시스템이 없기 때문에 대부분의 헝가리 사람들은 $\mathrm{EV}$ 자동차에 대한 충분히 동기를 부여가 안 되고 필요한 구매력이 부족하다.

\section{<리서치: R3> 체코}

체코는 1905년에 자동차를 만들기 시작하고 자국 브랜드 Skoda는 공산주의 시대에 건설되어, 1991년 폭스바겐에 인수 되어 회사의 4 번째 브랜드가 되었다. 또한 다른 두개의 세계 자동차 브랜드 도요타사와 PSA사가 2005년에(슬로바키아의 자매 공장에 투자한지 1년 후) 공장을 건설했다. CZ의 경쟁 우위는 독일의 자동차 소재에 대한 물리적 근접성, 노동력의 유연성, 근면함과 숙련된 노동력, 높은 수준의 기술 교육, $\mathrm{EU}$ 의 중간 수준 임금, 최첨단 기술 및 고도의 경쟁력 있는 생산 시설을 갖추고 있다. CZ는 2003년 2011년 동안(독일, 오스트 리아 또는 프랑스보다 시간당 연평균 높은 증가율)에서 가장 높은 생산성 증가율을 보였다. 체코는 유럽연합(EU) 5 위의 자 동차 생산국이며, 세계의 13번째로 최대의 자동차 생산국이다. 자동차 산업은 생산 $20.2 \%$, 수출 20.2\%(2007년)에서, 2014년 전체 산업생산의 $21.3 \%$, 수출의 $20.1 \%$ 를 차지했다. 자동차 산 업은 120,000 명 이상의 직원을 보유하는 체코 경제의 강력한 성장 엔진이다.

이미 자동차 산업에서 강한 가치 사슬을 구축하고 이웃 국 가들(슬로바키아)과 긴밀한 유대 관계를 구축하기 위해 헌신적 인 정부노력과 굳건한 자동차 산업 협회를 유지하고 있다. 체 코는 독일, 프랑스, 아시아 및 미국의 투자자들과 같은 부품 제조업체를 통해 해외 직접 투자를 유치해 왔다.

\section{<리서치: R4> 폴란드}

폴란드 자동차 산업에서 중요한 역할을 하는 주요 다국적 기업은 피아트, 오펠, 도요타, 폭스바겐, 마누치파거, 솔라리스, 볼보 및 스카니아 $\mathrm{AB}$ 가 해당된다. 이들 중, 폴란드에서 피아
트의 역사는 거의 1 세기에 걸쳐 강한 존재감을 지닌다. 20072009년 기간 동안 폴란드는 체코 다음으로 중부 및 동유럽에 서 2번째 승용차 생산국이었다(러시아 제외). 자동차부문의 생 산량은 주로 수출용으로 EU에 수출된다. 자동차 부문은 약 17 만 명의 직원을 고용하고 매출은 폴란드에서 2번째 규모이다. 자동차 생산은 전체산업 생산의 거의 $10 \%$ 에 달한다. 최근 몇 년 동안 폴란드는 체코와 슬로바키아에게 자동차 생산 거점으 로서의 지위를 잃어가고 있다. 2010년 이후로 폴란드에서 제 조된 차량의 수는 2013년 869,376대에서 583,258대로 감소했 기 때문이다.

\section{<리서치: R5> V4 + 루마니아}

$\mathrm{V} 4$ 에는 속하지 않지만, 루마니아는 EU에서 11번째로 규모 가 크며, 체코, 슬로바키아, 폴란드, 헝가리에 이어 중동부 유 럽에서 5 번째로 큰 자동차 생산국이다. 루마니아의 생산량은 자동차 부품을 많이 생산하는 V4 나라와는 달리, 르노(다키아) 와 포드사(Ford US)가 생산하는 거의 모든 자동차를 독점하고 있다. 루마니아는 자동차 조립 및 엔진 생산 공장으로 4곳(폴 란드 16곳, 체코 11곳, 슬로바키아 3곳과 비교해서)을 보유한 다.

\section{<리서치: R6> V4의 R\&D}

대부분 V4는 연구개발 투자의 수준이 낮으면 특히 슬로바 키아는 잠재적 경제 성장을 크게 저해하는 또 다른 요소가 되 고 있다. 2014년 슬로바키아는 GDP의 $0.89 \%$ 를 R\&D에 투자 했는데 이는 위기 이전 $0.46 \%$ 에서 현저히 개선되었지만 비세 그라드 국가 및 $\mathrm{EU}$ 평균인 $2.12 \%$ 보다 여전히 현저히 낮다. 실질 경제성장면에서 슬로바키아의 경우처럼, 비세그라드 그룹 중 가장 높은 성장에도 불구하고 연구개발 투자는 가장 낮은 수준이며, 비세그라드 그룹도 EU 15 개국 평균 수준보다 못 미 친다. 이러한 점에서 전기자동차의 혁신적인 개발보다는 부품 조립 체계의 유통으로 진화해 가고 있다.

\section{4. 전기자동차 산업 성장과 협력}

V4는 전기차의 기가 팩토리 핵심 부품생산과 기술 파트너 를 구축하는 역할을 하고 있다. 헝가리의 경우, 자동차 관련 생산은 저비용 노동과 인접한 주요 시장이 남아 있기 때문에 향후 꾸준히 성장하고 있다. 헝가리의 새로운 투자처를 위한 최상의 선택은 고용인 수가 부족한 동남부 지역에 있을 수 있 다. 이는 이머징 아시아와의 가장 적합한 협력의 시장과 도시 이기 때문이다. 또한, 잠재적인 신흥시장 참여자 외에도 기존 의 메르세데스-벤츠를 중부의 중심으로, 북부의 스즈키, 북서 쪽의 아우디, 서부의 GM 오펠(Opel)에 대규모 투자를 지원하 는 인프라와 노동력을 갖추고 있다. 동부 및 남부 지역의 헝가 리는 Borg Warner, Delphi Thermal, Delco Remy, Halla Visteon 및 $\mathrm{GM}$ Powertrain과 같은 선도적인 미국 자동차 부품 소재의 투자처이다. 미국의 Tesla Inc.도 네바다에 공장을 건 설 중이며 자동차와 유틸리티를 위한 친환경 전력으로 더 빨 리 전환할 수 있는 터전을 개척하고 있다. 테슬라는 유럽에서 도 자체 배터리 기가 팩터토리(제조기지) 설립으로, 유럽시장 에 도전적으로 임하고 있다.

Visegrad 그룹(V4), 오스트리아, 크로아티아, 슬로베니아는 수송, 에너지 및 디지털 문제를 공동으로 협력하고 있다. 서부 
발칸 지역 및 $\mathrm{EU}$ 와 우크라이나와 동부 파트너십의 확대에 초 점을 맞추어, 이 지역의 번영, 안정 및 안전에 도모하고 있다. 전기자동차의 e-수송에 관해서는, 사회 경제 개발을 위한 교통 인프라의 역할과 중요성을 인식하고 있다. V4는 시민의 이익 을 위해, 그리고 상호 이익을 위해 수송 및 교통 인프라 분야 의 대화와 협력을 강화하고 있다. 이러한 맥락에서 가능한 최 선의 방법으로 글로벌 협력에서 이익을 얻기 위해 V4와 중부 유럽 지역을 EU 및 세계 수송 기관에 맞게 완벽하게 통합해 야 한다.

또한 디지털 분야에서도 EU의 글로벌 경쟁력뿐만 아니라 유럽 사회의 미래 경제 성장과 일자리 창출에 배제될 수 없는 본격적인 유럽 디지털 단일 시장에 적극적으로 확립하고 있다. 이 목적을 위해 국경을 넘은 연결을 포함한 최신 디지털 기술 과 인프라의 개발 및 구현이 EU 내에서 지원하며, 시민과 기 업에 대한 초고속 인터넷에 저렴한 접속을 확보하는 것이 필 수적이다. 또한 데이터 경제, 국경을 초월한 전자상거래, 새로 운 비즈니스 분야의 개발, 데이터 보호, 사이버 보안, 디지털 기술 등의 과제도 해결해야 한다. 또한 자율 시스템, $5 \mathrm{G}$ 신흥 기업 등의 주요 미래 트렌드를 파악하고, V4 지역의 협력과 조정이 최우선이다.

북유럽(노르딕 협의체)은 자동차 산업의 발전과 협력을 도 모하고 있으나, 스마트한 환경 도시를 목적으로 한다. 따라서 북유럽 지속가능성 위원회는 자동차 타이어와 같은 다른 분야 에서 마이크로플라스틱 사용을 제한하고 있다. 이를 신중히 검 토하여 각 정부와의 대화와 이사회 본회의에 상정되어 투표로 결정하고 있다. 현재 환경과 연계하여 산업을 주도하고 있다. 이는 자동차 분야에서도 소재개발과 관련해서 전기자동차로의 전환으로 염두하고 있다.

\subsection{N5 노르딕(도시-전기차 융합시장)}

일반 연구에서 본고에서 북유럽은 2050년까지 승용차를 $100 \%$ 전기자동차에 침투시킨 노르딕 백본 전송 시스템의 최 적 계획을 제시한다(Graabak, Wu, Warland, \& Liu, 2016). 전 기자동차는 미래의 에너지 시스템에서 중요한 역할 수송 부문 에서의 온실 가스 배출을 줄일 수 있다. 그러나 전기자동차는 전력 소비를 증가시키고 전송 시스템에 혼잡을 유발할 가능성 이 있다. 전기자동차의 전력 통합에서 전력 시스템의 전력 소 비의 증가에 대처하고 사회 복지를 극대화하기 위해 북유럽의 송전 시스템의 최적 투자가 연구되고 있다.

실제 사례 연구로 보면, 시장 시뮬레이션 모델 $\mathrm{EMPS}(\mathrm{Efi}$ 멀티 지역 전력시장 시뮬레이터)와 2개의 전기자동차의 과금 시나리오, 즉 현물 가격 기준 시나리오와 가상의 충전 시나리 오를 사용하여 실시되고 있다. 전기자동차의 충전 전력은 단상 $16 \mathrm{~A}$ 의 $3.68 \mathrm{kw}$ 가정되어 있다. 민간 여객 함대의 완전한 전기 는 북유럽 지역의 연간 전력 수요를 약 $7.5 \%$ 증가시킨다. 편 리성의 높은 전송 용량의 증가는 가상 결제의 경우 가장 높지 만, 레퍼런스 사례와 비교하여 가상 및 현물 가격을 기반으로 과금으로 매우 낮다.

2015년 스웨덴의 자동차가 2019년까지 전체 전기자동차를 출시할 계획으로, $\mathrm{AB}$ 볼보의 전기 계획에 새로운 중점을 두고 있다. Volvo의 전기자동차 판매 총매출의 $10 \%$ 가 목표 항목이 다. 또한 새로운 하이브리드 전략의 첫 번째 요소는 90 시리즈 와 60 시리즈의 대형 하이브리드 자동차, 하이브리드 자동차를 확장하는 것은 볼보뿐이다.
2014년 중국-일본 투자 그룹은 파산한 스웨덴 사브 자동차 를 전기자동차 제조업체로 전환시켰다. 스웨덴의 자동차 메이 커는 National Electric Vehicle Sweden(NEVS) AB라는 컨소시 엄에 의해 개발하고 있다. 재정적 조건은 일본, 스웨덴 및 중 국 이해 관계자들이 결성한 NEVS는 스웨덴의 트롤허튼 (Trollhattan)에 의해 새로운 벤처를 설립되어, 스웨덴은 전기자 동차의 개발 및 제조에 관여하고 있다. 전기차량은 $\mathrm{Saab}$ 의 9-3 차량을 기반으로 하여, 일본의 첨단 기술로 전기에 적용되 고 2014년 판매되고 있다. 스웨덴은 "첨단" 일본 기술을 사용 하여 완전히 새로운 전기차의 모델을 개발하고 있다.

초기의 마케팅 및 판매는 북유럽이 전기자동차의 가장 크고 중요한 시장으로 간주되고 그 이후에는 전 세계적으로 확장되 는 중국의 제조에 중점을 두고 있다. 사브의 구매를 통해 중국 -일본 자동차 산업의 새로운 시대를 열었다. Saab는 제너럴 모터스(General Motors)에서 네덜란드 자동차 제조업체인 스파 이커(Spyker)에게 매각된 후 2011년 말에 파산했다. NEVS는 예비 부품 사업과 Saab 9-5 및 9-4X에 대한 권리를 제외하고 $\mathrm{Saab}$ 의 자산 대부분을 매입했다. 중국은 화석 연료에 대한 의 존도를 줄이기 위해 전기자동차에 막대한 투자를 하고 있다. 중국인들이 자동차 구매 증가에 따라 석유 공급 차량을 모두 구매한다면 세계 석유 공급은 충분하지 않기 때문에, 중국 수 요는 Trollhattan에서 사브 자동차를 인수함으로써 북유럽의 제 조가 제공할 수 있는 프리미엄 전기자동차를 확보하고 있다.

현재 노르웨이는 전기자동차 분야에서 세계 최고의 시장 중 하나이다. 전기자동차는 이미 스칸디나비아 국가에서 신차 판 매의 약 $24 \%$ 를 차지하고 있으며, 더 많은 수의 EV가 전시장 을 통해 시장점유율은 기하급수적으로 증가하고 있다(지난 2-3 년 동안 전기자동차 판매가 두 배로 증가했다). 노르웨이 정부 는 자치 차량, 대중교통 차량 및 택시를 배출가스가 없는 대체 차량으로 대체하고 전기자동차에 관심이 있는 소비자에게 매 력적인 인센티브를 제공함으로써, 수요가 증가하였다. 테슬라 (Tesla)사는 126명의 불만족한 노르웨이 고객(자동차 소유자) 에게 지불하기로 65,000 크로네(\$7,700 USD)를 고객들은 전 기자동차의 성능이 부합하지 않는다. "미친 가속의 모드"를 가 지고 있는 것으로 판명된 그들의 모델 S P85D 차가 그만큼 빠르지 않았다. 700 마력에 도달할 수 있을 것으로 추정되었던 모델은 단지 469마력에 도달했다. 테슬라 모델 S P85D는 노 르웨이에서 더 이상 제공되지 않지만 후속 모델인 P90D는 80 만 크로네(\$ 96,700)를 지불한다. 테슬라 기업이 급부상하고 있으며, LG화학으로부터 배터리를 공급받고 있다. 현재 자동 차시장의 수요는 S성장 곡선처럼, 전기차 시장으로 이동을 하 고 있다. 내연기관 자동차 시대에는 엔진, 변속기 등 주요 부 품 사업을 유럽이 주도권을 쥐고 있었는데 전기차 시대로 패 러다임이 변화되면서 상황이 바뀌고 있다. 배터리 분야에서 우 월한 기술을 쥐고 있는 한국, 일본이 시장 지배권을 갖는다. 반 면에 수소차 개발은 도요타와 BMW의 협력파트너, 메르세데스벤츠, 포드와 닛산과 파트너개발공유 등으로 이어가고 있다.

현재 글로벌 $\mathrm{EVs}$ 기업들의 1 회 충전 주행거리는 다음과 같 다. 쉐보레 볼트 $\mathrm{EV}$ 는 $383 \mathrm{~km}$, 현대자동차 아이오닉 $\mathrm{EV}$ : $191 \mathrm{~km}$, 기아자동차 쏘울 EV : $148 \mathrm{~km}$, 기아자동차 레이 EV : $91 \mathrm{~km}$, 르노삼성 SM3 ZE : $135 \mathrm{~km}$, 쉐보레 스파크 EV : $128 \mathrm{~km}$, 닛산 리프 EV : $132 \mathrm{~km}, \mathrm{BMW}$ i3 $94 \mathrm{~h}: 200 \mathrm{~km}$ (예상) 이다. 테슬라가 모델 3 를 세계 시장에 출시 때만 해도 거의 모델 3 가 전기차 대중화 시대의 본격적인 독점할 수 있었다. 그러나 $\mathrm{GM}$ 은 모델 3과 유사한 가격, 비슷한 주행거리를 이미 
갖추었고, 전 세계에 공급이 할 수 있는 완성도 높은 전기차를 생산하고 있기 때문이다.

<Table 3> Distribution of EVs in Norway and electric vehicles in Europe

\begin{tabular}{|c|c|c|c|c|c|c|}
\hline Company & Nisan & Volkswagen & Tesla & Mitsubishi & Other & Total \\
\hline 2015 & 30.4 & 23.4 & 13.6 & 10.6 & 22.0 & 100 \\
\hline
\end{tabular}

\begin{tabular}{|c|c|c|c|c|c|c|}
\hline & $\begin{array}{c}\text { Other } \\
\text { Europe }\end{array}$ & UK & Norway & Germany & Sweden & Denmak \\
\hline$\%$ & 48.6 & 20.0 & 12.9 & 12.1 & 5.1 & 1.3 \\
\hline 2015 & $6,524.1$ & $2,689.0$ & 1735.0 & 1.622 .1 & 686.3 & 171.6 \\
\hline
\end{tabular}

Source: Market Line(2016).

향후 도시와 기업 간의 진정한 혁신 프로세스를 가속화하는 방법으로-도시의 요구를 실제 혁신 프로세스의 지침으로 삼는 다양한 방법의 하나로, 전기자동차의 급격한 도입이다. 중소기 업 및 신생 기업이 블록체인기술로 실제 스마트시티 혁신에 참여시키는 방법에 중점을 두고, 민간 파트너십에서 글로벌 베 스트 프랙티스를 시연하고 있는 상황이다.

\section{4. 연구결과}

\section{1. 관계분석}

본 연구는 1) 비셰그라드 국가의 EVs(혁신 생산)과 노르딕 국가들의 $\mathrm{EVs}$ (유통 상용화 주도) 관계 분석 등을 실시하였다. $\mathrm{EU}$ 주요국의 제조 영역과 상용화 영역의 구분이 차별화되고 있다. 가장 좋은 사례 중 하나는 주로 디지털 제조 영역에서 생산성 효율성 향상 시스템을 제공한다. 아래 도표를 보면 노 르딕 국가와 비세그라드 그룹만의 제조비용의 격차는 커지고 있으며, 이는 비셰그라그드 국가의 제조업의 강점으로 여전히 지속될 것이나, 전기자동차 산업에서의 혁신도시와 전기차의 부품개발 등 융합측면에서는 단점으로 나타난다. 노르딕 국가 들을 <Table 4>처럼 제조업의 시간당 보상(Hourly Compensation in Manufacturing cost over time)이 매우 높게 나타난다(International Labor Comparisons, 2014). 이는 제조 업의 사용화에 대한 강한 경쟁력을 갖게 하며, 단순 노동의 제 조업보다는 전문 제조업의 상용화에 집중하는 이유가 된다.

그 이유는 V4 국내 최대의 공급 업체를 평가하면 수익의 $96 \%$ 는 외국인 기업이기 때문이다. 이러한 다국적 기업은 모국 에 일반적으로 R\&D 능력을 보유하고, V4지역에서 개발하거 나, 혁신의 가능성을 제한하고 있다.

미래에 V4의 실질 GDP와 제조비용은 스마트시티의 구축과 전기자동차 산업의 활성화와 연관성을 갖는다. 비셰그라드 4 는 동유럽의 주변국으로부터의 인구 유입정책으로 노동인구의 확대로 꾸준히 성장해오고 있다. 비셰그라드 4는 1989년 개방 이후 유럽의 제조기지 역할을 하고 있다. V4개국은 기술의 혁 신을 주도하기보다는 유럽의 혁신제조를 지원하는 구조이다. V4개국 중 헝가리와 폴란드가 혁신에 주도적인 역할을 했으나 슬로바키아가 급성장하고 있다.
폴란드와 슬로바키아의 실질 GDP성장율이 높고 유사한 것 을 보여준다. 이 두 국가가 최근의 비셰그라드 그룹의 성장을 주도하고 있기 때문이다. 반면에 헝가리와 체코가 성장률은 낮 지만 경제회복력이 빨라서 비셰그라드 그룹은 점차 <Table 5> Nordic 국가들처럼 잠재 생산에 따른 하이테크와 연계한 성장 증가율이 커지고 있다.

$<$ Table 4> Hourly Compensation in Manufacturing cost over time

\begin{tabular}{|c|c|c|c|c|c|c|}
\hline & $\begin{array}{c}\text { US } \\
\text { dollars }\end{array}$ & & $\begin{array}{c}\text { US = } \\
100\end{array}$ & & change & rate \\
\hline & 1997 & 2013 & 1997 & 2013 & & \\
\hline Norway & 25.88 & 65.86 & 112 & 181 & 39.98 & 1.6160 \\
\hline Switzerland & 30.43 & 63.23 & 132 & 174 & 32.8 & 1.3181 \\
\hline Belgium & 28.95 & 54.88 & 126 & 151 & 25.93 & 1.1984 \\
\hline Sweden & 25.04 & 51.10 & 109 & 141 & 26.06 & 1.2935 \\
\hline Denmark & 23.72 & 51.07 & 103 & 141 & 27.35 & 1.3689 \\
\hline Germany & 29.18 & 48.98 & 127 & 135 & 19.8 & 1.0629 \\
\hline Australia & 18.89 & 47.09 & 82 & 130 & 28.2 & 1.5853 \\
\hline Finland & 22.36 & 44.57 & 97 & 123 & 22.21 & 1.2680 \\
\hline Austria & 24.91 & 44.37 & 108 & 122 & 19.46 & 1.1296 \\
\hline France & 24.87 & 42.85 & 108 & 118 & 17.98 & 1.0925 \\
\hline Netherlands & 22.46 & 42.26 & 98 & 116 & 19.8 & 1.1836 \\
\hline Ireland & 17.42 & 41.98 & 76 & 116 & 24.56 & 1.5263 \\
\hline Italy & 19.77 & 36.92 & 86 & 102 & 17.15 & 1.1860 \\
\hline $\begin{array}{l}\text { United } \\
\text { States }\end{array}$ & 23.04 & 36.34 & 100 & 100 & 13.3 & 1 \\
\hline Canada & 18.49 & 36.33 & 80 & 100 & 17.84 & 1.25 \\
\hline $\begin{array}{c}\text { United } \\
\text { Kingdom }\end{array}$ & 19.30 & 31.00 & 84 & 85 & 11.70 & 1.0119 \\
\hline Japan & 22.00 & 29.13 & 96 & 80 & 7.13 & 0.8333 \\
\hline Spain & 13.96 & 28.09 & 61 & 77 & 14.13 & 1.2622 \\
\hline $\begin{array}{c}\text { New } \\
\text { Zealand }\end{array}$ & 12.04 & 25.85 & 52 & 71 & 13.81 & 1.3653 \\
\hline Singapore & 12.16 & 23.95 & 53 & 66 & 11.79 & 1.2452 \\
\hline Israel & 11.62 & 22.25 & 50 & 61 & 10.63 & 1.22 \\
\hline South Korea & 9.24 & 21.96 & 40 & 60 & 12.72 & 1.5 \\
\hline Argentina & 7.55 & 19.97 & 33 & 55 & 12.42 & 1.6666 \\
\hline Greece & 11.61 & 18.96 & 50 & 52 & 7.35 & 1.04 \\
\hline Portugal & 6.44 & 12.90 & 28 & 35 & 6.46 & 1.25 \\
\hline Slovakia & 2.84 & 12.31 & 12 & 34 & 9.47 & 2.8333 \\
\hline $\begin{array}{c}\text { Czech } \\
\text { Republic }\end{array}$ & 3.25 & 12.17 & 14 & 33 & 8.92 & 2.3571 \\
\hline Estonia & NA & 11.66 & NA & 32 & NA & NA \\
\hline Brazil & 7.03 & 10.69 & 31 & 29 & 3.66 & 0.9354 \\
\hline Hungary & 3.05 & 9.44 & 13 & 26 & 6.39 & 2 \\
\hline Taiwan & 7.07 & 9.37 & 31 & 26 & 2.3 & 0.8387 \\
\hline Poland & 3.29 & 9.25 & 14 & 25 & 5.96 & 1.7857 \\
\hline Mexico & 3.47 & 6.82 & 15 & 19 & 3.35 & 1.2666 \\
\hline Philippines & 1.24 & 2.12 & 5 & 6 & 0.88 & 1.2 \\
\hline
\end{tabular}

Source: Author's own edited. 
<Table 5> High tech exports, percent of manufactured exports Comparison of $\mathrm{V} 4$ and N5(Nordic)

\begin{tabular}{|c|c|c|c|c|c|c|c|c|}
\hline \multirow{2}{*}{ Year } & \multicolumn{3}{|c|}{ V4(Visegrad countries) } & \multicolumn{4}{|c|}{ Nordic } \\
\cline { 2 - 9 } & HU & PL & CZ & SK & SW & DK & NO & FI \\
\hline 2000 & 26.53 & 3.36 & 8.49 & 3.63 & 22.77 & 21.44 & 16.76 & 27.36 \\
\hline 2001 & 24.23 & 3.17 & 10.05 & 3.86 & 17.39 & 20.82 & 18.19 & 24.36 \\
\hline 2002 & 24.93 & 2.88 & 14.55 & 3.21 & 18.17 & 22.46 & 20.64 & 24.15 \\
\hline 2003 & 25.76 & 3.07 & 13.52 & 3.8 & 16.26 & 20.2 & 16.83 & 23.74 \\
\hline 2004 & 29.05 & 3.34 & 13.19 & 5.48 & 17.41 & 20.31 & 17.44 & 20.93 \\
\hline 2005 & 25.83 & 3.79 & 12.95 & 7.44 & 16.94 & 19.61 & 16.09 & 25.06 \\
\hline 2006 & 24.12 & 3.74 & 14.32 & 6.72 & 16.1 & 18.45 & 17.22 & 22.31 \\
\hline 2007 & 23.79 & 3.04 & 13.24 & 5.35 & 11.53 & 16.98 & 14.73 & 17.98 \\
\hline 2008 & 23.3 & 4.32 & 13.56 & 5.26 & 11.2 & 15.58 & 14.85 & 17.21 \\
\hline 2009 & 24.94 & 6.1 & 14.56 & 5.7 & 12.91 & 17.5 & 15.8 & 13.96 \\
\hline 2010 & 24.07 & 6.69 & 15.3 & 6.77 & 13.7 & 13.94 & 16.15 & 10.94 \\
\hline 2011 & 22.73 & 5.87 & 16.28 & 7.1 & 13.38 & 13.75 & 18.46 & 9.27 \\
\hline 2012 & 18.09 & 6.95 & 16.08 & 9.21 & 13.4 & 14.22 & 18.83 & 8.55 \\
\hline 2013 & 16.34 & 7.81 & 14.79 & 10.31 & 14.06 & 14.33 & 19.14 & 7.21 \\
\hline 2014 & - & 8.7 & 14.92 & 10.22 & 13.88 & 14.42 & 20.74 & 7.86 \\
\hline 2015 & - & 8.73 & 14.9 & 10.29 & 14.26 & 15.96 & 20.52 & - \\
\hline 2016 & - & 8.46 & 13.96 & - & - & 15.57 & 19.46 & - \\
\hline
\end{tabular}

Source: Author's own edited.

2020년까지의 Horizon 계획의 방향을 보면, 첫째, 세계적인 엘리트 수준의 대형 $\operatorname{RTD}$ (연구기술개발) 그룹을 양성하고, 둘 째, 글로벌 기업의 R\&D센터를 확장 설립하고 강화한다. 셋째, R\&D 클러스터 지역 내에서 집약하고 SMEs에게 생산에 필요 한 지원과 서비스 제공한다. 넷째, R\&D의 투자 개발을 통하여 창업소기업들이 글로벌 시장에서 역량을 확보할 수 있도록 돕 는다. 다섯째, 혁신적인 신생기업들에게 착수 자금을 지원하여 자유롭게 활동하도록 한다(UN, 2017).

2010년 폴란드는 총 연구예산은 $0.74 \%(G D P)$ 수준이었으 나, 2020년 1.7\%(GDP)까지 증대한다. 2014-2020년까지 폴란 드는 2007-2013년 혁신경제의 경영프로그램과 지식개발 프로 그램(76억 유로의 추가 예산)을 통해서, 혁신을 이룩하고자 한 다. 이는 V4는 소규모 기금을 통해서 R\&D와 혁신 협업에 투 자금을 마련하고 있다. 4개국 비셰그라드 펀드(Visegrad Fund) 의 지원활동이 혁신적인 R\&D를 별도로 이끌고 있다. 비셰그 라드 기금은 크게 세 가지로 구분된다. 첫째, 교부금 프로그램, 둘째, 모빌리티 프로그램, 셋째, 예술가 레지던시 프로그램 등 이다.

\section{2. $\mathrm{EVs}$ (전기차) 경쟁과 스마트시티의 한국적인 관점}

본 연구는 아래와 같이 분석하였다. $\mathrm{EVs}$ (전기차) 경쟁과 스 마트시티의 한국적인 관점을 반영하여 6 개국으로 각각 선정하 였다. 미래에 $\mathrm{V} 4$ 의 경우, 전체 전기차의 배터리 부품 수단으로 써, LG화학이 유럽 전기차 배터리 시장을 선도할 생산기지를 폴란드 브로츠와프(Wrocław)에 세워, '한국-미국-중국-폴란드'를 연결하는 글로벌 4각 생산 체제를 구축하고 있다. 삼성 SDI는
헝가리의 Geod에 유럽 전기차 배터리 공장을 세웠다. 이에 한 국의 해외 배터리 산업을 확장시키고 있는 롯데 케미컬, SK도 비셰그라드 국가에 구축하고 있다.

유럽의 첫 대규모 전기차용 리튬배터리 생산기지인 LG화학 의 폴란드 전기차 배터리 제조과정에서 유럽은 최대 생산능력 면에서 '전극'부터 '팩'까지 생산하는 완결형 생산기지로, 앞으 로 LG화학의 시장 선점을 가속화한다. EU의 전기차 산업을 선도 역할로써 핵심 생산 허브로 구축할 수 있도록 모든 역량 을 집중하고 있다. 폴란드 남서부지역 브로츠와프(코비에르지 체)에 들어서는 전기차 배터리 생산라인은 약 4,000 억 원(축구 장 5 배 이상 크기인 4만 $1,300 \mathrm{~m}^{2}$ 규모)을 투자해서 2017년 하 반기 생산을 시작하고 있다. 그러나 북유럽의 경우, 전체 전기 차 상용화의 '지속가능한 교통수단'으로, 화석연료 자동차를 탈 피해 전기자동차가 상용화되고 있는데 머물지 않고 수소연료 에 연료전지를 단 자동차로 북유럽 노르딕 시장을 2015년까지 공동으로 시장을 지배하려 했다. 한국과 일본, 덴마크와 노르 웨이의 수소 자동차 관련 기업들이 북유럽 시장을 선도하고 있다. 민관동반자관계의 협력을 강조하며 한국 기업은 이를 확 장해 기여한다.

북미시장의 경우, 테슬라가 세계 전기차 시장의 $30 \%$ 를 차 지하는 북미 전기차 시장에서 압도적인 1 위를 기록 중이다. 일본의 배터리 제조사, 파나소닉이 테슬라의 신차가 출시될 때 장착되는 신차용 배터리(OEM) 공급을 독점하고 있기 때문이 다. 테슬라는 일본 파나소닉과 협력해 전기차 배터리를 자체적 으로 기술개발하고 자국 내 생산한다. 반면에 경쟁사 $\mathrm{GM}$ 의 전기차 배터리는 LG화학이 공급하고 테슬라보다 가격도 최대 $40 \%$ 이상 저렴하다.

이를 극복하기 위해 현지 스마트도시와 연결된 전기차 확대 가 중심이 되는 새로운 교역의 방향이 요구된다. 북유럽 스마 트도시로 자체 전기공급과 전기차 연계 구조물 산업을 형성해 가고 있으며, 동유럽은 이를 전기차 기반으로 한 허브도시를 구상하고 있다. 예를 들면, 그린 스마트시티로써, 스웨덴 말뫼 시에서 새로 구입한 차량은 모두 친환경 모델이며 기존의 차 량은 바이오가스로 신차는 수소-배터리식 전기자동차 등으로 교체하며 나머지 시내버스의 $50 \%$ 이상은 친환경(바이오가스) 연료를 사용한다. 이는 스마트시티와 연계된 전기자동차의 토 털 솔루션 개념으로 현지 생산유통을 결정해야 한다.

체코 정부는 오스트라바(Ostrava)의 Visegrad 4를 위해 조 직된 스마트시티 컨퍼런스를 통해, 스마트도시 개발과 관련하 여 V4 도시 간의 협력을 시작하기위한 새로운 전통을 구현하 려 한다. 사회 경제적 구조와이 네 국가의 역사는 매우 유사하 며 직면한 문제도 유사하기 때문이다. 이에 관하여, 모든 정부 비서 국무 장관은 그들의 계획과 개념을 갖고 있으며, 헝가리 와 폴란드는 기술과 별개로 대중의 참여를 큰 의미로 간주하 는 가장 포괄적인 전략을 시도한다. 체코는 민간 부문의 참여 로 지속 가능한 이동성과 근대화 에너지에 중점을 두고 있으 나 슬로바키아는 스마트도시 개발 전용 프로그램을 개발하지 못하고 있다.

EU가 스톡홀름의 GrowSmart H2020 스마트시티 프로젝트 매니저는 퀘스트 발표자로서 12가지 스마트 솔루션을 기반으 로 한 계획을 발표했기에 비세그라드 그룹도 개발하고 있다. 스마트도시 프로젝트는 전형적으로 구조적 $\mathrm{EU}$ 기금을 사용하 여 구현되었다. 헝가리에서 Miskolc시는 스마트도시 승객에게 대중교통 개선에 대한 정보를 제공하고 교통 정보를 개선하고 지열을 통한 지역난방을 구현하고 있다. 체코의 스마트도시는 
loT 장치의 확산과 LoraWan 및 iBeacon과 같은 통신 플랫폼 을 지원하는 기술의 급속한 발전에 관한 도입하는 것이다. 이 점에서 북유럽협의체에 비해 비세그라드 그룹의 스마트도시는 전기자동차와 연계성이 부족한 상태이다.

체코와 폴란드를 조사해 보면, 수출 금액은 지속적으로 증 가하고 있으나, 외국인 직접투자는 점차 감소하고 있다. 앞서 서 제조비용 면에서 언급했듯이, 이러한 다국적 기업은 모국에 서 R\&D 능력을 확보하거나 글로벌 $M \& A$ 를 하기 때문에 V4지 역에서 투자개발하거나, 혁신의 투자는 감소하기 때문이다. V4 그룹이 아니면서, 자동차생산국가인 루마니아는 여전히 FDI가 일정하게 유입되고 있다. 이는 전기자동차를 생산 확대가 될 경우, 투자의 폭이 커질 것으로 보인다. 전기자동차와 관련 부 품소재산업이 더 빠르게 V4지역으로 FDI가 유입될 것이며, 이 에 따른 $\mathrm{V} 4$ 국가들은 기술 개발력을 창출해야 하고 소유해야 할 것이다.

전기자동차의 OEM은 공급 업체에게 더 낮은 비용과 높은 품질을 제공하고 더 나은 제품 생산과 기술 지원에 접근할 수 있도록 상당한 압력을 행사하여 생산성 향상에 동기 부여한다. 자동차 산업은 연계성이 강하다. 따라서 자동차 클러스터가 슬 로바키아의 $\mathrm{OEM}$ 을 통한 혁신 엔진이 될 잠재력이 있다. 주요 자동차 제조업체가 슬로바키아 시장에 진입했을 시, 전기자동 차 산업이 자체 네트워크의 하청 업체를 선도하게 한다. 따라 서 슬로바키아 국내에서 가장 큰 공급 업체를 평가할 때 매출 의 $96 \%$ 는 외국 소유의 공급 업체에서 산출된다. 이러한 다국 적 기업은 일반적으로 본국에서 R\&D 역량을 갖추고 있어 지 역 혁신 잠재력을 제한하기 때문이다. 여전히 현재 23개의 슬 로바키아 하청 업체가 R\&D를 하고 있으며 모두 OEM 업체협 력과 연결되어 있다. 이는 아래의 <Table 6>은 IVF의 2015년 자동차와 같은 내구재(전자장비 포함)에 대한 질문에 '예'라고 대답한 설문의 비율(\%)을 보면, $\mathrm{V} 4$ 가 하나의 국가처럼 상호 간의 자동차 구매력이 약하기 때문이다.

$<$ Table 6> V4 Citizen's car purchasing experience

\begin{tabular}{|c|c|c|c|c|}
\hline & HU & PL & CZ & SK \\
\hline HU & $\mathrm{x}$ & 4 & 13 & 24 \\
\hline PL & 10 & $x$ & 27 & 29 \\
\hline CZ & 11 & 11 & $x$ & 56 \\
\hline SK & 10 & 5 & 33 & $x$ \\
\hline
\end{tabular}

현재 한국 현대의 아이오닉 자율주행모델은 미국 자동차공 학회가 분류한 5 단계 가운데 완전 자율주행 수준을 의미하는 레벨 4를 만족시킨 상태이지만, 현대차가 아이오닉EV를 선두 로 전기차 시장에서 점차 시장 확대를 나타내는 대는 여전히 기술개발이 요구된다. 이번 자율주행 모델로 2017년 자동차 시장을 자율주행차로로 스마트도시가 형성되기 때문이다. 세계 최초로 수소연료 전기차의 양산체제를 구축한 현대자동차가 차세대 수소차로 선도하려하지만, 글로벌 수소차 및 친환경차 시장에서의 시장지배력 강화는 단독으로만 구축되지 않는다. 국내 시장의 확대보다는 자동차의 본고장인 유럽에서 상용화 를 도전적으로 구축, 파트너십이 중요하다. 반면에 일반 제품 의 신뢰가 가장 강한 영향력을 미치는 구입상 품질도 중요하 다(Kim \& Shim, 2017). 현재 신뢰가 바탕이 된 전기차 시장이 확대 발전시켜야 수소차도 동반해서 시장 지배력을 갖추게 되
기 때문이다. 북유럽은 한국 수소차의 상용화의 시험대가 될 것이며, 이는 전기화학적 반응을 하는 연료전지의 특성상영하 30 도 이하의 추운 지방에서의 시동성 문제도 대두되었다. 수 소전기차 상용화는 북유럽과 $\mathrm{V} 4$ 의 파트너십으로 기술 지배력 (시장 표준화)을 넘어 시장 지배력으로 확대되어야 한다.

\section{5. 결론}

\section{1. 요약과 시사점}

본 연구는 $\mathrm{V} 4$ 가 여전히 자동차의 국내수요 뿐만 아니라, 전 기자동차의 해외수요도 창출해야 하는 어려움에 처해 있다. $\mathrm{V} 4$ 는 미래의 자동차의 제조 기지를 통해 상업화를 만들어가야 한다. 한국 수소차가 한국 기업이 전기자동차 마케팅의 관점에 서 스마트시티를 구현하는 데 없어서는 안 될 필수 요소임을 강조한다. 그러나 북유럽과 동유럽을 비교할 때 지역 경제에 대한 전기차의 생산경제의 개념을 달성하기 위해, 현재를 기업 의 생존노력으로는 독립적으로 스마트시티나 전기차를 성장을 증가시키지 못하고 있다. EU 내에서의 공유 산업 시스템으로 조명해 보면, 전기차의 기술 개발로의 유럽은 스마트도시와 연 계된 지역 전기자동차의 상용화에 초점을 맞추고 있기 때문이 다. 그리고 북유럽은 북극 또는 불모의 지역에서도 상용화가 가능하며, 미래도시에 대한 $\mathrm{EVs}$ 의 상업화가 우선시 되고 있다. $\mathrm{V} 4$ 는 전기자동차와 관련해서 기존 자동차의 통합 기술전략을 강조하면서 가장 어려운 측면 중 하나는 스마트시티의 경제적 역할이다.

V4는 전기자동차의 기술 성장으로 또 다른 도약의 터전이 되고 있으며, 북유럽은 우선적으로 상용화를 통해 LTE처럼 세 계 표준화에 더 앞당기기 위해 전기자동차에 대한 수요를 증 대하고 있다. 전기자동차는 현재 수요가 적으나 대도시에서 확 대되고 전체 산업의 경쟁력을 향상시킨다. 그러나 노르딕 국가 와 같은 공공 기업처럼, 스마트시티를 중심으로 빠르게 성장하 는 전자 통합 산업이 아니라면 민간 부문에 적극적으로 참여 하지 않을 것이다.

$\mathrm{V} 4$ 와는 달리 북유럽은 스마트시티를 통해 국제표준화를 선 점하고 이에 따른 시장지배력을 확보하려 할 것이다. 그러나 이에 앞서서 전기자동차의 생산기지로써, 독자적인 기술개발까 지 V4 그룹이 갖춘다면 글로벌로 확장되는 전기자동차 시장을 $\mathrm{V} 4$ 경제의 혁명을 일으킬 것이다. 전기자동차, 하이브리드 자 동차를 포함한 IOT 및 자동차 시장의 변화가 유럽 전역으로 확대되고 있다. 이는 전기자동차처럼 기술성장 S-곡선의 수요 는 상용화로 이끄는 성장 영역이 되기 때문에, $\mathrm{AI}$ 로 연결된 스 마트 공유도시의 여건조성을 앞서서 대비해야 한다. V4는 기가 배터리 공장이나, 부품소재산업, 완성 전기자동차 제조기지로 다시금 경제부흥을 가져올 것이 확실시 된다. 여기에 연구개발 로 기술 지배력을 확보한다고 잠재적인 선진국으로 진입할 시, 그 영향을 미치는 것으로 나타나 이 연구결과와 어느 정도 일 치한다.

\section{2. 한계}

4차 혁명시대에 블록체인이 연계된 IoT와 함께 전기자동차 의 개발은 독자적인 자동차의 활용이 가능해질 수 있도록 전 
기자동차에 배치할 수 있다. 이를 계량적으로 수치적 모형으로 나타내는 것은 무의미하며, 국제저널에서 예측적 계량분석이 적다. 전기차의 S-곡선 성장에 따른 상용화로 시장지배력을 점 유하려고 해야 한다. 그러나 본 논문에서는 그 성장시점을 통 계화해서 결과를 도출하기 어려움이 있다.

\section{References}

Ambroziak, Ł.(2012). Intra-Industry Trade of the Visegrad Countries: The Case of Automotive Industry. Prace Naukowe Uniwersytetu Ekonomicznego we Wroclawiu, Part 1(267), 11-24.

Chodkowska-Miszczuk, J., Kulla, M., \& Novotny, L.(2017). The role of energy policy in agricultural biogas energy production in Visegrad countries. Bulletin of Geography. Socio-Economic Series. 35(35), 19-34.

Coo, B. M.(2017). Developing SMEs' Export Success Factors for Distribution Reinforcement. Journal of Distribution Science, 15(10), 65-80.

Coo, B. M., \& Seo, D. S.(2016). A Study of Business Model of Logistics $\mathrm{O} 2 \mathrm{O}$ Industry - Focused on Korean Freight Information Network Business. Korea Logistics Review, 26(6), 13-23.

Graabak, I., Wu, Q., \& Warland, L., \& Liu, Z.(2016). Optimal planning of the Nordic transmission system with $100 \%$ electric vehicle penetration of passenger cars by 2050. Energy, 107(1), 648-660.

Harnisch, S., Frank, C., \& Maull, H.(2011). Routledge Advances in International Relations and Global Politics. London: Routledge.

International Visegrad Fund(2006). Visegrad Group? Central European Constellation. Warsaw: Adam Mickiewicz Institute press.

International Visegrad Fund(2013). EU Integration Issues-Visegrad Countries and the South. Warsaw: Caucasian Institute for Economic and Social Research press.

International Visegrad Fund(2011). Two Decades of Visegrad cooperation. Bratislava: IVF press.

International Visegrad Fund(2013). EU Integration IssuesVisegrad Countries and the South. Caucasian Institute for Economic and Social Research press. Two Decades of Visegrad cooperation. Bratislava: IVF press. Visegrad Group - Central European Constellation. Warsaw: Adam Mickiewicz Institute press.

International Visegrad Fund(2015). official website, Annual report of the V4 Presidency. Retrieved March 26, 2015 from http://visegradfund.org/?download=down loads/media/annual_reports/ivf_Visegrad-Fund15.pdf.

International Visegrad Fund(2015). Official Website, Annual report of the V4 Presidency. Retrieved March 26, 2015 from http://visegradfund.org/?download=down loads/media/annual_reports/ivf_Visegrad-Fund15.pdf.

International Visegrad Fund(2017). Official website, Annual report of the V4 Presidency. Retrieved October 10, 2017 from http://visegradfund.org/?download= downloads/media/annual_reports/ivf_Visegrad-Fund 17.pdf.

Kim, H. S., \& Shim, J. H.(2017). The Effects of Service Qualities on Customer Satisfaction and Behavioral Intention in Coffee Shops. International Journal of Industrial Distribution \& Business, 8(5), 95-109.

KITA(2017). K-stat. Retrieved October 10, 2017 from http://stat.kita.net/stat/cstat/multy/MultyPeriodCtrList.s creen.

Kurekova, L., Salner, A., \& Farenzenová, M.(2013). Implementation of Activation Works in Slovakia: Evaluation and Recommendations for Policy Change. Bratislava: Slovak Governance Institute.

Leggett, D.(2015). Sweden: Volvo Cars plans electric car for 2019, Aroq-Just-Auto. Global News, 4-4.

Market Line.(2016). Norway - Hybrid \& Electric Cars. London: United Kingdom.

Newby, A. G.(2009). In Building a Nation Few Better Examples can be Found: Norden and the Scottish Parliament. Scandinavian Journal of History, 34(3), 307-329.

OECD(2016). Global EV Outlook 2016-Two million and counting, Retrieved November 1, 2016 http://www.oecd.org/publications/global-ev-outlook-20 17-9789264278882-en.htm.

OECD(2017a). OECD Economic Outlook: Statistics and Projections(database). Retrieved October 16, 2017 from https://stats.oecd.org/Index.aspx?DataSetCode =EO93_INTERNET.

OECD(2017b). Global EV Outlook 2017-Two million and counting, Retrieved November 22, 2017 http://www.oecd.org/publications/global-ev-outlook-20 17-9789264278882-en.htm.

Panico, C.(2017). Strategic interaction in alliances. Strategic Management Journal. 38(8), 1646-1667.

SARIO(2015). Automotive Sector in Slovakia(Slovak Investment and Trade Development Agency). Bratislava: Automotive Industry Association of the Slovak Republic(ZAP SR).

Seo, D. S.(2017). The investment point on cooperative innovation in EVs for the spoke-smart cities: Focused on Nordic countries and Korea. The Journals of Economics, Marketing \& Management, 5(3), 1-11.

Seo, D. S.(2014). The Expansion Strategy for New Route between Korea-Hungary. Journal of Distribution 
Science. 12(6), 59-65.

Seo, D. S.(2015). Central Eastern Europe's Pattern of Industrial Development and Regional Structure in Market Distribution. Journal of Distribution Science.
13(6), 17-23.

UN(2017). The United Nations Commodity Trade Statistics Database. Retrieved November 22, 2017 from https://comtrade.un.org/data. 